\title{
Upper Third of the Esophagus
}

National Cancer Institute

\section{Source}

National Cancer Institute. Upper Third of the Esophagus. NCI Thesaurus. Code C12253.

The upper one third of esophagus in which the muscle layer is composed of muscle cells of the striated type. 